\title{
Integrated Remediation Strategies for Sustaining Agrobiodiversity Degradation in Africa.
}

\author{
Duruigbo C.I ${ }^{1}$., Okereke-Ejiogu,E.N ${ }^{2}$.,Nwokeji, E.M ${ }^{1}$., \\ Peter-Onoh,C.A ${ }^{1}$.,Ogwudire,V.E. ${ }^{1}$ and Onoh, P.A. ${ }^{2}$ \\ ${ }^{I}$ Department of Crop Science and Technology, ${ }^{2}$ Department of Agricultural Extension, School of Agriculture and \\ Agricultural Technology, Federal University of Technology PMB 1526 Owerri, Nigeria
}

\begin{abstract}
Sub-Saharan Africa is richly endowed with natural agro biodiversity that is being threatened by the impacts of climate change, deforestation, flooding, water and air pollution, genetic erosion, incessant hunting and collection of wild plants and animal species as well as natural disasters. The challenge is thus for the people and government to work together in safeguarding the environment and preserving biodiversity by adopting an integrated conservation strategies which include; application of indigenous knowledge in biodiversity conservation, adoption of organic and sustainable farming practices, setting up of botanic and zoological gardens, gene banks and a deliberate government policy aimed at environmental protection and agro biodiversity conservation to avoid extinction of endangered plant, and animal species.
\end{abstract}

Keywords; Agro biodiversity, climate change, genetic-erosion, deforestation, organic-framings, botanic and zoological garden, government policy.

\section{Introduction}

The concept of agro biodiversity refers to the variety and variability of animals, plants and microorganisms that are used directly or indirectly for food and agriculture, including crops, livestock, forestry and fisheries. It comprises the diversity of genetic resources and species used for food, fodder, fiber, fuel and nonharvested species that support production such as soil micro-organisms, predators, pollinators and those in the wider environment that support agro-ecosystems (agricultural, pastoral, forest and aquatic) as well as the diversity of the agro-ecosystems (FAO, 1999a).

Africa has rich and varied biological resources forming the continents natural wealth on which it's social and economic system are based. These resources are of global importance for the world's climate, development of agriculture, industrial activities, pharmaceutical production, construction and tourism.

Africa harbors about one quarter of the worlds 4,700 mammalian species including 79 species of antelope, more than 2000 species of birds and at least 2000 species of fish and 950 amphibian species. The African mainland also contains between 40,000 and 60,000 plant species and about 100,000 species of insect, spiders and other arachnids. Eight of the worlds 34 biodiversity hotspots are in Africa (UNEP, 2008)

Agro biodiversity is actively managed by male and female farmers whose intervention is critical to the survival of many components of agro biodiversity.

The Atlas Mountain in North Africa shelter rich pine and oak forests as well as rare species such as wild olive and Saharan myrtle.

The Tibet Mountains in Southern Libya provide prime habitat for migratory birds and a key refuge for threatened wild life species.

In Egypt about 7\% of the countries bird population consists of migratory species which appear on a seasonal basis. Significant concentrations of the world's bird population are found in the Mediterranean shores of Egypt and Black sea (Bird life International, 2005)

The horn of Africa has the continents highest number of endemic reptiles and a number of threatened antelopes such as the gerenuk (Litocranius walleri) due to over-hunting, drought and habitat loss.

African forests support many wild vertebrate species such as chimpanzees, Jentink's duiker, mandrills and the pygmy, hippopotamus that are in danger of extinction.

The lowland forests of West Africa are home to more, than one quarter of Africa's mammals including more than 20 species of primates. About six species are endemic to the upper Guinea forests and nine species to the forests of Cameroon and Nigeria. The mandrills are the world's largest monkeys that live in the rain forest of Congo basin which covers Cameroon, Central African Republic, Democratic Republic of Congo, Equatorial Guinea and Gabon.

The Mau complex - which is the largest forest in Kenya covers some 400,000 hectares and is one of the five main catchment areas known as " the water towers of Kenya-" it feeds major lakes, three of which are cross boundary. The Mau complex generates over $\$ 270$ million annually from tourism, energy and tea (UNEP 2009, Kenya wildlife Service, 2008) 
Africa is home to numerous wetlands of international significance and covers some one percent of the continents' total surface area found in virtually all countries (W. R.I. 2010).

In terms of water resource Africa is endowed with hundreds of lakes and rivers. There are about 677 lakes in Africa of which 88 are principal lakes. There are about 80 trans-boundary Rivers and lake basins of which the 17 largest ones have over 100,000 kilometers catchment area. The largest fresh water lake in Africa and the second largest in the world is lake Victoria (Africa's lakes Atlas 2006).Lake Victoria basin is richly endowed with both natural (terrestrial and aquatic) and agricultural biodiversity, however the natural habitats are under threat due to increasing human-induced pollution. Alien invasive species have also contributed to biodiversity loss. Lake Victoria basin is located on the upper Nile river basin and occupies an area of about 250,000 square kilometers with 68,870 square kilometers covered by the lake. The lake is shared by Kenya, Uganda and Tanzania. The Lake supports the most productive freshwater fisheries in the world with annual fish harvests in excess of 500000 metric ones worth $\$ 600$ million annually (UNEP, 2008).

The river Nile constitutes a key biodiversity corridor across the Sahara desert but is heavily affected by human activities. In coastal and marine ecosystems Africa is facing many challenges including decline in fish stocks due to pollution and acidification from land based sources.

In many coastal areas in Africa, habitats such as the mangroves, sea- grass beds salt marshes and shellfish reefs continue to decline, threatening highly valuable ecosystem services as well as removing significant quantities of carbon dioxide from the atmosphere.

The Sahara desert occupies 4.6 million square kilometers or 10 percent of the land mass of Africa, with relatively rich fauna. There are about 70 mammalian species 20 of which are large mammals, 90 species of resident birds and about 100 species of reptiles (UNEP, 2006).

The deserts of Namibia possess rich succulent flora and an exceptional plant endemism with about $69 \%$ of its plants gone into extinction due to the effects of grazing, agriculture, mining, road construction and other human activities (UNEP, 2006).

The continued productivity of existing crops and livestock hinges in part on harnessing the genetic variation within each species. Tropical rain forests in sub- Saharan Africa cover about 7 per cent of the earth's surface with more than half of the world's biota as well as wild populations of crop and livestock species (Wilson, 1988).

About 5000 African plant species have been negatively impacted due to climate change. Also in South Africa fynbos and succulent Karoo biomes losses is estimated at 51-61\% (Boko et al, 2007).

The rate of agro biodiversity degradation in Africa is alarming leading to losses of important plant and animal species.

This research paper shall highlight the factors responsible for agro biodiversity degradation in Africa and also offer integrated sustainable remediation measures to conserve and preserve agro biodiversity in the sub-region.

\section{Factors Responsible for Agro biodiversity Degradation in Africa Climate Change}

Climate change is a major concern in relation to the minerals sector and development. It is potentially one of the greatest threats to the environment, biodiversity and ultimately to our quality of life (Facing the future, 2002).

Africa is one of the most vulnerable continents to climate change and variability a situation aggravated by the interaction of multiple stresses such as poverty, bad governance and ecosystems degradation as well as low adaptive capacity. Sea level rise and climate variability could result to destruction of aquatic and coastal biodiversity. Several highly populated delta regions such as the Nile and the Niger are at great risk of erosion, flooding and salinisation with resultant agro biodiversity deterioration (Barrie, 2009).

There is a strong linkage between temperature and plants (Weber and Stocks, 1998). Obioha (2002), observed that forest ecosystems are vulnerable to temperature abnormality causing instability and disturbances at the landscape level (Turner et al, 1998). Forest disturbances such as fires drought, convectional storms, wind storms, erosion and landslide, affect agro biodiversity negatively (Justice and Townsend, 1981). Njoku (2009) reported that a pronounced from 1970- 2005 in Southeastern Nigeria resulted to alterations in species composition population products and service.

Rainfall is a climatic attribute whose variability will obviously affect biodiversity performance. Rainfall varies unpredictably in amount, intensity and distributions and variations produce phenomenal drought resulting to biodiversity decline or total extinction of valuable species.

In the Sahel region floods could subside for 2 to 4 days thus causing great havoc to the terrestrial ecosystems and biodiversity (Tauner and Hamburg, 1992).

Wind factor of climate is known to erode top soils and deposited on natural and artificial water- ways causing flooding. Dry winds increase vapor - transpiration thus limiting moisture available to plants, causing 
them to display xerophytic, geophytic and therophytic behaviors in response to the harsh climate, thus majority of these life forms become vulnerable when critical limits of climatic variability are exceeded.

Sub-Saharan Africa is housing about 1/5 of all known species of plants, mammals and birds in the world; this rich biodiversity is currently being threatened by climate change impacts (Boko et al, 2007).

Mountainous regions are projected to suffer from temperature increases. Under climate and land use change habitats are projected to shift spatially or disappear completely forcing species to migrate (Mclean et al, 2005). About 5000 African plant species have been negatively impacted by climate change. Also in South Africa, Fynbos and succulent Karoo biome losses is estimated at 51-61\% (Boko et al, 2007).

\section{Deforestation.}

Disappearing forests and other vegetal forms in Africa is a great threat to animal's life. Loss of forest due to bush-fires, and deliberate cutting of trees implies destruction of saprotrophs, creeping and climbing plants, reptiles, arboreal organism and a wide range of wild animals. It is important to note that deforestation promotes low soil carbon sequestration, increasing volatilization, thermal impact and severe land, water and air degradation. Agricultural development logging and ranching are identified as the main causes of deforestation (Cataneo, 2002).

Deforestation reduces canopy cover thus exposing the soil to erosion and loss of forest functions in terms of hydrology and biodiversity (Liniger and Critchley, 2007). Deforestation also disrupts; nutrient mineralization, soil carbon storage, trace gas fluxes, transformation of aqueous solutes and processing of water pollutants respectively Interactions among plants, soil hydrogy and micro-organisms regulate nutrient cycling in ecosystems (Barthuiya et al, 2008) and these interactions vary in time and space (Vitousek et al, 1994), but affect plants productivity (Zak et al, 1994) thus indicating their dependence on inputs of reduced carbon in the soil through litter (Allen and Schlesniger, 2004).

Muul (1993) reported that the number of logs harvested in the tropics is not necessarily the major threat to the survival of tropical biodiversity but the destructive manner in which logs are harvested leading to negative impacting on biodiversity and meso- fauna in the rain forest vegetation of Western Nigeria (Nurudeen et al, 2009). Logging exposes soils to intense sunlight and drastically reduces ant population (Badejo et al, 2005) as well as other soil organisms (Crossley and Blumberg, 1983).

\section{Water and Air Pollution}

The incessant use of agro-chemicals such as fertilizers, insecticides and herbicides in conventional agriculture has resulted in significant water and air pollution.

Drivers of atmospheric change such as agriculture, biomass burning, fossil fuel combustion, industrial processes interact with their effect on the environment namely; ultra violet radiation, global warming, photochemical smog, global oxidation efficiency, acid rain, visibility and corrosion to alter biodiversity. There exists relationship between sources of atmospheric trace gases, aerosols and environmental consequences as chemistry of the atmosphere has evolved with biodiversity (Andreal and Dickson, 1995).

\section{Problems of Pesticides}

Contaminated drinking water is increasing all over the world especially in Sub-Saharan Africa. Water and air pollution threaten both aquatic organisms and terrestrial ecosystem.

Pollutants such as nitrogen oxides, carbon monoxide and volatile organic compounds lead to ozone pollution in urban environments and to a global increase in ozone concentrations in the lower atmosphere. Ozone in the lower atmosphere is the third largest human-induced contributor to global warming after carbon dioxides and methane (Barrier, 2009) Acid rain and tropospheric ozone have widespread adverse effects on terrestrial and aquatic ecosystems, human health and building materials.

\section{Genetic Erosion.}

The main cause of genetic erosion as reported by almost all countries is the replacement of local crop and livestock species by improved varieties and breeds. Often the number of varieties is reduced when commercial varieties are introduced into traditional farming system (FAO, 1996) while FAO states that some indicators of genetic erosion have been developed, few systematic studies of the gene erosion of crop genetic diversity have been made.

\section{Hunting and Collection of Wild Plants and Animals For Household Consumption.}

Most important wild animal and crop species in Africa is rapidly being devastated through hunting and harvesting without deliberate efforts to retain some of these important crops and animal species for posterity and procreation. In Burkina Faso, and throughout West Africa Sahel, rural woman carefully collect the fruit, leaves and roots of native plants such as baobab tree (Adansonia digita) red sorrel leaves (Hibiscus saddarifa), Kapok 
leaves (Ceiba pentandra) and tiger nut tubers (Cyperus esculentus L.) for use in the families diet. These supplement the agricultural grains (Millet and Sorghum) that provide only one part of the nutritional spectrum (I.K. Notes 2001). Due to poverty, hunters set traps or use guns to catch important animals such as grass- cutter, monkeys, kangaroo and antelopes, for consumption or for sale. These practices tend to reduce the population of wild animals which may eventually go into extinction.

\section{Natural Disasters.}

The occurrence and magnitude of natural disasters such as earthquakes, landslides, cyclones, will certainly lead to the outright degradation of both aquatic, terrestrial, and arboreal ecosystems and biodiversity. These natural disasters are not rather rampant in Sub-Saharan Africa.

\section{Integrated Conservation and Preservation Measures For Agro-Biodiversity. Application of Indigenous Knowledge In Preserving Biodiversity.}

Farmer's traditional ecological knowledge is historical, cumulative and dynamic, building upon farmer's earlier experiences from his ancestors and adapting to the socio-economic changes of the present (Johnson, 1992; Berkes, 1999; Doubleday, 1993; Nakashima, 1993). Local knowledge includes mental inventories of local biological resources, animal breeds, local plants and tree species. It may include information about trees and plants that grow well together or indicator plants that show the soil salinity or fertility or are known to flower at the beginning of the rains. It includes practices and technologies such as seed treatment, storage methods, tools used for planting and harvesting. Local knowledge encompasses belief systems that play a fundamental role in people's livelihood, health, protection and replenishing of the environment. Over time humans have developed their unique capacity to think, adapt to changes, foresee, accumulate and pass on intellectual wealth to subsequent generations (Ewert et al, 2004).

Local knowledge also includes farmer's experimentation on the integration of new plant or tree species into existing farming systems (Blaikie, 1992). Knowledge involves selection, rejection, creation; development and transformation of information. For instance local farmers using their wisdom of knowledge prefer to store their farm produce using local plant extracts (biocides) which is known to be safe, easily biodegradable, ecologically-compatible and socio-culturally acceptable to farmers. Examples of such plants whose extracts are currently used are; neem plant (Azadiracta indica) Bitter kola (Garcinia cola) cashew (Anarcardium occidentale) Lemon grass (Cymbopogon citrates) bitter leaf (Vernonia amydgalina) orange Citrus sinensis) Ginger (Zingiber officinale) soy bean (Glycine max) and a host of other plants that are locally available, cheap, non toxic to man and livestock, environmentally- friendly and highly compatible with agro biodiversity.

Millions of small-scale subsistence farmers in sub-Sahara Africa are professionals hence should be recognized and treated as such (Chambers, 1980) because their expertise represents the largest knowledge resource base not yet mobilized and tapped in the development enterprise (Hatch, 1976). Local farmers make deliberate efforts to collect and preserve important wild plant and animal species and domesticate them to prevent its extinction from the ecological system. Taboos are local laws aimed at protecting the elimination of certain tree or livestock species by banning the cutting of such trees or killing of the wild animal. This is intentionally put in place to preserve biodiversity through local customs. Offenders are usually penalized in accordance with customary regulations.

\section{Organic Farming Practices.}

Organic farming is a type of system that involves less intensive use of land by applying cultivation practices which exclude or significantly restrict the use of synthetic chemicals such as pesticides and fertilizers. Organic agriculture focuses on environmental protection and the use of natural resources including the maintenance of soil structure and fertility, water resources and biodiversity. Organic farming practices are already practiced by millions of small scale farmers in sub-Sahara Africa to boost food production, protect the environment and preserve Biodiversity. These practices include;

\section{Cover Cropping.}

Farmers normally include cover crops such as sweet potato (Ipomia batatas), "Egusi melon" (Colocynthis citrullus), and muccuna (Mucuna pruriens) to suppress weeds, conserve moisture and provide conducive micro-climate for the component crops. Cover cropping increase the activities of soil micro fauna, micro flora and other soil microbes resspectively, as well as increased soil biological activity, soil temperature regulation, ecosystem functioning and the survivability of species that would have been threatened by high soil temperatures due to climate change. 
Integrated Remediation Strategies for Sustaining Agrobiodiversity Degradation in Africa.

\section{Agro-Forestry Systems}

African farmers usually and deliberately retain certain tree and shrub species in their cropping systems because they recognize that these tree or shrub species have long term beneficial effects on both the soil and the environment - this practice by farmers will boast soil fertility, prevent soil erosion, control weeds, store more carbon and increase crop yields.

Bene et al, (2007) defined agro-forestry system as a "sustainable management system for land that increases overall production, combines arable crops and forest plants and animals simultaneously or sequentially and applied management practices that are compatible with the local cultural pattern". Agro-forestry systems are extremely dynamic with resources capable of coping and mitigating climate change in the long run and conserving biodiversity (Musa, 1987). The challenges to sustainable agricultural development in Africa are multifaceted; however it is clear that agro forestry is one important option that can successfully address the challenges of food security, poverty, environmental and biodiversity degradation in the continent.

\section{Use of Organic Manure/Mulch}

Organic nutrient sources capable of boosting soil nutrient status include plant residues, leguminous cover crops, mulch, green manure, poultry manure, goat droppings, pig waste, cow dung, compost manure and farm yard manures (FYM), under continuous cropping systems (Tandon, 1993).

The use of organic mulches such as Siam weed (Chromolaena odorata) mulch has been reported to increase soil organic carbon, phosphorus, potassium, calcium and magnesium contents especially at the rate of 10 and 12 tons per hectare respectively (Duruigbo et al, 2008). The use of organic soil amendments for managing soil fertility is inevitable following the current trend of soil physical, chemical and biological degradation (Obi and Ebo, 1995).

\section{Conservation Tillage}

Conservation agriculture operates in three principles which aim to disturb the soil minimally, cover soil as much as possible and intercropping, such that the soil and its inhabitants are not exposed to the harsh and excruciating climate. Conservation agriculture puts back the Stover on the soil (residue management) controls grazing and stocking, opens narrow planting furrow with a ripper or makes small planting holes, uses compost, green manure, farm yard manure, legumes and municipal wastes respectively. The application of conservation agriculture will boost food production, protect the environment and conserve biodiversity which is also in harmony with the new partnership for African Development (NEPAD) sectoral priority aimed at eradicating extreme poverty and hunger and ensure environmental sustainability (I.I.R.R. AND ACT, 2005).

Tree- based improved fallow system and the biomass transfer systems are helpful in areas with low inputs and low crop productivity (Place et al, 2005). Within the African farming systems woody plants protect the environment, act as a companion crop, shade to livestock produce green manure, fodder, fuel-wood, stakes for farm use and produce fruits, fiber and ornamentals, provide homes for arboreal organisms and reclaims impoverished African soils (Sanchez et al, 1997).

In summary, organic farming builds a pedosphere replete with micro, meso-flora and fauna and promotes organic matter build up in the soil through principles aimed at reducing tillage, diversifying cropping systems eliminating the use of pesticides and fertilizers, use of organic manure, applying crop rotation, cover cropping green- manuring, night soils, mulches, agro-forestry systems and rehabilitating degraded lands by planting trees - these practices create a healthy soil that boost biodiversity (L.E.I.S.A, 2008). Sustainable agriculture as a local practice and research priority has been practiced by resource- poor farmers in Africa in response to widespread recognition of the need to balance food production with a healthy environment that will sustain biodiversity (N.R.C 1989).

Farmers in their wisdom used ecological principles for the design and management of natural resources and the use of resource- conserving practices in farming. The system relies practically on farmers' indigenous farming knowledge and selected modern technologies to manage diversity and incorporate biological principle and resources into farming systems to boost food production, reduce climatic anomaly and preserve endangered species of plants and animals (Pretty, 1995)

In Sub-Sahara Africa evidence shows that regenerative and resource- conserving technologies and practices by farmers has both environmental and economic benefits to farmers, the community and biodiversity, with substantial crop yields often with a few or no external input (Bunch, 1990, UNDP 1992, Shah, 1994; Pretty, 1995).

The ability of the soil to capture and store carbon is a function of texture structure, rainfall, temperature, farming system and soil management (Lal, 2004), tillage (Del- gross et al, 2008), cropping intensity (Ortega et al, 2002) and nitrogen inputs to the soil.The adoption of conservation tillage which minimizes soil disturbance with adequate residue cover contributes to soil organic matter built up in the arid and semi-arid areas of sub-Sahara Africa. 
Conservation tillage reduces erosion and carbon losses that are critical to climate change. The potential carbon sequestration under conservation tillage per year could reach $0.1 \mathrm{mg} / \mathrm{ha}^{-1}$ for rainfed crops and rangeland, (Rosemberg et al 1999). Thus conservation tillage as a sustainable agricultural practice that has the potential to mitigate green house gas effect, improve soil structure, and increase soil water infiltration, soil water holding capacity and enhanced biodiversity.

\section{Setting up of Botanic Gardens.}

Experience have shown that most farmers deliberately collect wild plant species especially those that have medicinal value and domesticate, nurture and multiply them in special farms or botanic gardens. The aim of this practice is to preserve these plant species from going into extinction.

\section{Zoological and Gardens/Game Reserve}

Farmers also hunt for wild animals and keep them in zoological gardens. Governments of various countries in Africa have developed zoological gardens and game reserves where wild animal species are kept and taken care of by livestock health workers. This effort by governments is aimed at preserving important wild animals that are already going extinct due to un-regulated hunting activities.

\section{Establishment of Gene Banks}

Globally, there are about six million crop species contained in more than 1,300 gene banks contain huge amounts of un-tapped and endangered biodiversity. In Sub-Saharan Africa most of the landraces kept in the gene banks are dying due to chronic under finding by government (A.C.I.R., 2009).

Government should collaborate with local people whose local knowledge of important wild crop and animal species i.e. enormous and ensure that adequate documented and kept in data banks.

\section{Policy Option.}

Favorable policies aimed at protecting the environment and preserving biodiversity should be put in place by various governments in Sub-Saharan Africa. A strong information and communication intervention strategy should be put in place by government through the electronic and mass media to educate and inform people on the need to protect the environment, conserve and preserve biodiversity. This is particularly necessary now that the rate of agro-biodiversity degradation is increasing in the continent. Policies that will encourage public private partnership in agriculture and environmental protection are inevitable to ensure that food production is not carried out to the detriment of the environment and biodiversity.

\section{Conclusion.}

The protection of the environment and conservation of agro-biodiversity is crucial to food security, ecosystem functioning and health security of people in Sub-Saharan Africa. Hence efforts and practices needed to sustain the environment and preserve biodiversity must be encouraged at the local and regional levels in the continent.

[1]. (A.C.I.A.R) Australian Center for International Agricultural Research. 2009"Millennium Development Goals". In Partners in Research for Development. ISSN - 1031 - 1009.

[2]. Allen, A and W. Schlesinger. 2004."Nutrient limitations to microbcal biomass and activity in loblolly pine forests". Soil Biol Biochem., 36 Pp $581-589$

[3]. Andreae,M.O.and R.E. Dickson, 1995. "Sustainability and changing atmosphere. Assessing change in chemical and physical climate". In munasinghe M. and W. Shearer (eds)Defining and measuring sustainability: The biophysical foundations. United Nations University (UNU) and the World Bank. Washington D. C. U. S. A PP 117 - 134.

[4]. Badejo, M. A., G. Tian, and I. O. Okoh. 2005.Litter transformer as ecosystem engineers. Sustainable Agro ecosystem 2, Pp 91 94.

[5]. Barrie, A. P. 2009. "Climate change" The science, impact and solutions CSIRO publishers, Australia.

[6]. Barthuiya A. R; A Arunachalam, H. N. Pandey, K. Arunachalam and M. I. Khan, 2008. Effects of anthregenic disturbance on soil microbial biomass. C. N and P in a tropical rainforest ecosystem of Assam, Northeast India. Malaysian Journal of Soil Science 12. Pp $31-44$.

[7]. Bene, J. G., Beall, H. W. and Cote, A. 1997. Tree, Food and people. "Land management in the tropics". An I .D. R. C. publications. 0842

[8]. Berkes, F. 1999. "Sacred Ecology".Traditional Ecological knowledge and Resource management. Philadelphia. P. A Taylor and Francis (eds) In "The way of Development " Edited by Mario- Blasser, Harvey, A. F. and Glenn M. Pp $72-87$.

[9]. Birdlife International 2005. "Strategy for the conservation and sustainable management of IBAs in Africa. $2005-2015$. Nairobi, Kenya.

[10]. Blaikie, P. M. 1992. In Long N and Long A (eds). Battlefields of knowledge. The interlocking theory and practice in social research and development, London. Routtledge.

[11]. Boko, M. M. L. Pamy et al (eds) 2007 "Africa” In "climate change": impacts, adaptation and vulnerability. Contribution of working group II to the fourth assessment report of Inter-governmental Panel on Climate Change. Cambridge. U. K. University, press. 
[12]. Bunch, R. 1990. Low- input soil restoration in Honduras. The Contarranas farmer - to -farmer extension programme. Gate- keeper series. S. A. 23, London. International Institute for Environment and Development

[13]. Cattaneo, A. 2002. Balancing agricultural development and deforestation in the Brazilian Amazon. International Food Policy Research Institute. Washington DC. Research report 129. 146pp.

[14]. Chambers, R.1980.”The Small Farmer Is a Professional” Ceres. Pp 19-23.

[15]. Crossley, D. A. And A. Y. Blumberg, 1983. Comparison of soil surface arthropod populations in convectional tillage, No- tillage and old field systems. Agroeco- system 8: Pp 249 - 253.

[16]. Del - Grosso, S.J., A.D. Haworson and W.J.Parton, 2008. Testing "DAYCENT model" simulations of corn yield and nitrous oxide emissions in irrigated tillage system in Colorado. Journal of Environmental Quality, 37: Pp 1363 - 1389.

[17]. Doubleday, J. 1993. "Finding common ground, natural law and collective wisdom" In J. Inglis (ed). Traditional Ecological knowledge: concepts and cases. Ohawa. International programme. Traditional Ecological Knowledge and International Development Research Centre Pp $41-53$.

[18]. Duruigbo C.I., M.O. Ofor, Nkwopara U. and B.N. Ndukwa "Efficacy of Siam weed mulch on soil nutrient status and maize yield in a degraded Isohypethemic Arenic Kandiudult. International Journal of Agriculture and Rural Development 11 (1) Pp $11-15$.

[19]. Ewert, A. W., Baker, D.C. and Bissix G.C. 2004. Integrated resources and environmental management The Human Dimension. CABI publishing. Wallingford Pp 290.

[20]. Food and Agricultural Organization (FAO) 1999a, "Agricultural Biodiversity" Multifunctional

[21]. character of agriculture and land conference. Background paper 1, Maastricht, Netherlands. September 1999.

[22]. Food And Agricultual organization (FAO) 1996. "Global plan of action for the conservation and sustainable utilization of plant genetic resources for food and agriculture”, Leipzig Germany, June 1996.

[23]. Facing the futher. 2002. "A report to the International Institute for Environment and Development. Pp 52. http/www.iied.org

[24]. Hatch, J. 1976. The corn farmers of Motupe." A study of traditional farming practices in Northern Coastal Peru". Land Tenure. Centre Monograph. University of Wisconsin, Madison.

[25]. Indigenous Knowledge Notes (IK.) 2001 I.K. notes number 30. "Indigenous knowledge and HIV/AIDs. Ghana and Zambia.

[26]. I.I.R.R \& Act (International Institute of Rural Reconstruction And African Conservation Tillage) 2005. "Conservation agriculture". A manual for farmers and extension workers in Africa. Majestic Printing works Ltd Kenya Pp 251.

[27]. Johnson. M. 1992. Lore: "Capturing Traditional Environmental knowledge" Ottawa. In Dene Culture, Institute and International Development Research Centre "In The way of Development”, Mario Blesser, Harvey A. Geit and Glenn McCrae (eds) Pp 78-88.

[28]. Justice, C.O. and J.R.G. Townsend. 1981. The use of land set data for land cover inventories of Mediterranean lands. In Townsend, J.R.G (ed) Terrain analysis and remote sensing. George Allen and Urwin, London.

[29]. Lal R., 2004. Soil carbon sequestration, impact on global climate change and food security. Science 304 Pp $1623-1627$.

[30]. LEISA (Low External Input and Sustainable Agriculture) 2008 "Living soils" LEISA 24 (2) Pp4-5.

[31]. Lininger, H. and W. Critchley. 2007 "Where the land is greener" Case study of soil and water conservation initiatives worldwide. (WOCAT. CTA, FAO, UNEP and CDE) Stampfil A9. Bern 364pp.

[32]. Mclean C.J. 2005. “African Plant diversity and climate change” In Annals of the Missouri Botanical Garden. 92 (2) Pp 139-152

[33]. Musa, G. M. 1987. The role of Gliricidia sepium in Yam-based Cropping system Dept. of Agronomy. University of Ibadan, Nigeria.

[34]. Muul, I. 1993. Tropical forests, integrated conservation strategies and the concept of critical mass and biosphere (MAB) Digest No. 15 UNESCO, France.

[35]. Nakashima, D. 1993 “Astute observers on the sea ice edge, Imut Knowledge as a basis for arctic co-management” In J. Inglis (ed) Traditional Ecological knowledge. Concepts and cases. International Development Research Centre Pp 99-100.

[36]. N.R.C (National Research Council). 1989. "Alternative agriculture”. Washington D.C., National Academy press.

[37]. Nurudeen, T. A., S. A. Adebola, A. E Onyeanusi, E .N. Ekpo and V.O Dania 2009. Post impact assessment of logging on mesofauna and soil properties. International Journal Soil Science. 1. (1) Pp 1-7.

[38]. Njoku, J D. 2009. Temperature anomaly and responses by rainforest cover- potential implications, for food availability in southeastern Nigeria Proceedings of the International conference on global food crisis held at Owerri, Nigeria April 19- 24 2009. Pp 281-287.

[39]. Obioha, I. B. 2002. "Evidence of climate change and why it is concern for Nigeria". Paper presented at the Canada- Nigeria climate change capacity development project NEST-GCST Awareness raising workshops. Ibadan Centre for Energy Research and Development Obafemi Awolowo University, Ile-Ife.

[40]. Obi, M. E; and Ebo, P. O. 1995. The effect of organic and inorganic amendments on soil physical properties and maize production on a severely degraded sandy soil in Southern Nigeria, Bio- Resources Technology 51 Pp 117-123

[41]. Ortega, R. A., G. A. Peterson and D. G. Westfall. 2002. Residue accumulation and change in soil organic matter as affected by cropping intensity in no- till dryland agro- ecosystem. Agronomy Journal. Vol. 94 Pp $944-954$.

[42]. Place, F. M., Adato, p; Hebinck and M. Omosa. 2005. The impact of agro forestry based soil fertility replenishment practices on the poor in western Kenya. International Food Policy Research Institute. Washington D.C. Research report 142, 166pp.

[43]. Pretty, J. N. 1995. Regenerating agriculture: policies and practices for sustainability and self- reliance. London - Earthscan publications Ltd.

[44]. Rosenberg, N. R., R. C. Izauralde and E. I. Malone. 1999. Introduction to proceedings on carbon sequestration in soils. Science; monitoring and beyond. Workshop. Pp vii - xii.

[45]. Sanchez, P., K. D. Shepherd, M. J. Soule, F. M. Place, R.J. Buresh and A. N. Izac. 1997. Soil fertility replenishment in Africa. An investment in natural resource capital. Soil Science Society of America Special publication No. $51.46 \mathrm{pp}$.

[46]. Shah, Parmesh. 1994. Village managed extension systems in India “implications for policy and practice” In Jan - Scones' and John Thompson (eds) beyond farmer first. London Intermediate Technology publications.

[47]. Tandon H. I. S. 1993. Soil fertility and fertilizer use: an overview of research for increasing and sustaining crop productivity. Workshop on the integration of natural and man-made chemicals in sustainable agriculture in Asia. International Council of Scientific Union. New Delhi. Sept 13-19, 1993.

[48]. Tauer, W. and G. Humborg, 1992. Run -off irrigation in the Sahel zone - remote sensing and geographic information systems for determining potential stress. CTA, Wageningen. The Netherlands. 192pp.

[49]. Turner, M. G; 1998. Factors affecting succession: lessons from large infrequent natural disturbances. Ecosystem I: Pp 511 - 523.

[50]. UNEP. 2008. Africa: Atlas of our changing environment. Nairobi, Kenya.

[51]. UNEP. 2006. Global Deserts outlook. Nairobi, Kenya.

[52]. UNEP 2009. "Biodiversity on the move to 2010" www. unep.org U.N.D.P (United National Development Programme) 1992. The benefits of diversity. An incentive towards sustainable agriculture. New York. 
[53]. Vitousek, P. M., D. R. Turner, W. J.Parton and R. L. Sanford. 1994. Litter decomposition on the Muna loa environment matrix. Hawaii. Patterns, mechanics and models. Ecology 75: PP $418-429$

[54]. Weber M. G. and B. J. Stocks. 1998. Poorest fires and sustainability in the Boreal forests in Canada. AMBIO 27: Pp 545 - 550

[55]. Wilson, E. O. 1988. "The current state of Biological Diversity" In E. O. Wilson and F. M. Peter (eds) Biodiversity. Pp 3 - 18. Washington D. C. National Acad. Press.

[56]. W. R. I. (World Resource Institute) 2010. http/www.earthtrends.org

[57]. Zak D. R., D. Tilaman, R. ParmenterC. N. Rice, F. M. Fisher, J. Vose, D. Milchuchas and W. Martin. 1994. Plant production and soil microorganisms in late succession-ecosystems: A conditional scale study. Ecol. 75. Pp 2333-2347. 